\title{
PERANGKAT LUNAK PEMBELAJARAN SISTEM BILANGAN PECAHAN DESIMAL DENGAN METODE NUMERIK
}

\author{
Yanti Rambe*1, Saut Dohot Siregar ${ }^{\# 2}$ \\ ${ }^{1,2}$ Teknologi Ilmu Komputer, Universitas Prima Indonesia \\ Jalan Sekip Simpang Sikambing, Sumatera Utara \\ *yantirambedyahoo.com
}

\begin{abstract}
This study aims to create software that can assist students in understanding the division of decimal fractional systems with precise and correct with numerical method approach, and display the results of the division correctly. The design of software built with Microsoft Visual Studio 2010 which is a learning application that teaches users how to calculate decimal fractions with the concept of numerical methods. The design method in this software is by using Waterfall method. The software is designed with a quiz so it can attract students' interest to learn, providing an easy explanation of how the decimal fractions are broken down gradually. The designed device can run on a desktop computer so it does not require internet to run it.
\end{abstract}

Keywords: Software, Number Systems, Decimal Fractions, Numerical Methods, Interest in Learning.

Abstrak - Penelitian ini bertujuan untuk menciptakan perangkat lunak yang dapat membantu siswa dalam memahami pembagian sistem bilangan pecahan desimal dengan tepat dan benar dengan pendekatan metode numerik, serta menampilkan hasil pembagiannya dengan benar. Perancangan perangkat lunak dibangun dengan Microsoft Visual Studio 2010 yang merupakan aplikasi pembelajaran yang mengajarkan penggunanya cara-cara menghitung pecahan desimal dengan konsep metode numerik. Metode perancangan pada perangkat lunak ini adalah dengan menggunakan metode Waterfall. Perangkat lunak yang dirancang dilengkapi kuis sehingga dapat menarik minat siswa untuk belajar, memberikan penjelasan yang mudah mengenai cara pembagian pecahan desimal secara bertahap. Perangkat yang dirancang dapat dijalankan pada komputer desktop sehingga tidak memerlukan internet untuk menjalankannya.

Kata Kunci: Perangkat Lunak, Sistem Bilangan, Pecahan Desimal, Metode Numerik, Minat Belajar.

\section{PENDAHULUAN}

Pecahan desimal adalah pecahan yang penyebutnya dibagi dengan 10,100,1000 dan sebagainya serta ditulis dengan menggunakan tanda koma secara manual dan pada komputer ditulis dengan tanda titik. Pecahan desimal biasanya merupakan pecahan yang tidak dapat dibagi habis dan selalu memiliki sisa bagi. Contoh pecahan desimal seperti0,35; 1,$25 ; 6,7$ dan 0,003 .

Matematika merupakan salah satu mata pelajaran yang diajarkan disetiap jenjang pendidikan. Matematika adalah suatu bidang ilmu yang melatih penalaran supaya berpikir logis dan sistematis dalam menyelesaikan masalah dan membuat keputusan. Untuk mempelajari matematika memerlukan cara tersendiri karena matematika bersifat khas yaitu abstrak, konsisten, hierarki, dan berpikir deduktif.
Permasalahan matematika yang diselesaikan secara manual atau dengan metode analitik kadang memberikan hasil perhitungan yang kurang tepat dikarenakan perhitungan manusia kadang memiliki kesilapan dan batas. Oleh sebab itu, proses perhitungan matematika yang diselesaikan dengan metode numerik tentunya akan memberikan solusi dan nilai yang tepat dikarenakan proses perhitungan dilakukan oleh komputer. Metode Numerik merupakan suatu teknik/metode penyelesaian permasalahan yang diformulasikan secara matematis dengan cara operasi hitungan atau aritmatik [1].

Selain itu permasalahan yang sering terjadi adalah kebanyakan siswa merasa ketakutan terhadap pelajaran matematika. Hal ini dikarenakan karena mereka beranggapan bahwa pelajaran matematika adalah mata pelajaran yang sangat sulit 
dan mereka umumnya tidak memahami materi yang diberikan oleh guru.

Hal inilah yang menjadi alasan penulis untuk membuat "Perangkat Lunak Pembelajaran Sistem Bilangan Pecahan Desimal dengan Metode Numerik". Dengan adanya perangkat lunak yang menanganipembagian pecahan desimal ini diharapkan dapat mempermudah siswa dalam memahami pelajaran matematika khususnya dalam proses pembagian pecahan decimal.

\section{LANDASAN TEORI}

Aplikasi adalah salah satu perangkat lunak yang memiliki kumpulan perintah program yang digunakan untuk melakukan beberapa aktivitas manusia, seperti: perniagaan, permainan, pelayanan masyarakat, periklanan atau prosesproses lainnya yang dilakukan manusia. Kumpulan aplikasi komputer yang digabungkan menjadi suatu paket disebut sebagai suite aplikasi (applicationsuite). Contohnya: MicrosoftOffice dan OpenOffice.org, yang menggabungkan aplikasi pengolah kata, lembar kerja dengan beberapa aplikasi lainnya.

Metode Numerik adalah metode penyelesaian persoalan matematika secara pendekatan yang di dalamnya hanya menggunakan operasi aritmatika seperti “+”,"-“,”x” dan “.”.Atau dapat dikatakan bahwa Metode Numerik adalah sekumpulan aturan untuk menyelesaikan persoalan matematika secara pendekatan dengan hanya menggunakan operasi aritmatika" [1].

Hal-hal khusus yang dimiliki oleh metoda ini adalah: adanya proses penghitungan yang berulangulang (iteratif) yang membawa konsekwensi adanya alat bantu untuk proses otomatisasi dari iterasi tersebut yaitu (program) komputer. Komputer adalah mesin penghitung elektronik yang cepat dan dapat menerima informasi input digital, kemudian memprosesnya sesuai dengan program yang tersimpan di memorinya, dan menghasilkan output berupa informasi. Sebelum suatu permasalahan bisa diselesaikan dengan bantuan komputer diperlukan langkah langkah antara lain: proses pemodelan matematis dari situasi nyata, penyediaan input dan data yang cukup bagi model, dan pembuatan algoritma program.

Pembagian pecahan desimal biasanya dilakukan dengan mengubahnya menjadi bentuk pecahan terlebih dahulu lalu kita misalkan soalnya $1,7: 0,2$.

1. Kita ubah desimal menjadi pecahan setiap ada angka dibelakang koma maka dihitung $10^{-1}$ dan seterusnya. Apabila ada dua angka dibelakang koma maka akan menjadi $10^{-2}$. $10^{-1}$ artinya $1 / 10$. Jadi $1,7: 0,2$ dapat dituliskan menjadi $17 / 10: 2 / 10$

2. Selanjutnya ubah pembagian menjadi perkalian pecahan dengan cara seperti ini:

$17 / 10 \times 10 / 2$

2/10 dibalik menjadi 10/2 maka berdasarkan rumus matematika pembagian akan menjadi perkalian.

3. Kemudian kalikan antara pembilang dengan pembilang dan penyebut dengan penyebut maka menjadi:

$(17 \times 10):(10 \times 2)=170 / 20=17 / 2=8,5$

4. Maka didapatkan hasil dari $1,7: 0,2=8,5$ [2].

Waterfall Model merupakan salah satu model proses dasar seperti spesifikasi, pengembangan, validasi dan evolusi dengan mempresentasikannya sebagai fase-fase proses yang berbeda seperti analisis dan definisi persyaratan, perancangan perangkat lunak, implementasi dan pengujian unit, integrasi dan pengujian sistem, operasi dan pemeliharaan [3].

Pada Gambar 1, Sommerville menjelaskan bahwa tahap-tahap utama dari waterfall model 
adalah memetakan kegiatan-kegiatan

pengembangan dasar yaitu:

1. Analisis dan Definisi Persyaratan

Proses mengumpulkan informasi kebutuhan sistem/perangkat lunak, melalui konsultasi dengan user system. Proses ini mendefinisikan secara rinci mengenai fungsi-fungsi, batasan dan tujuan dari perangkat lunak sebagai spesifikasi sistem yang akan dibuat.

2. Perancangan Sistem dan Perangkat Lunak Proses perancangan sistem difokuskan pada empat atribut, yaitu struktur data, arsitektur perangkat lunak, representasi antar muka, dan detail (algoritma) procedural.

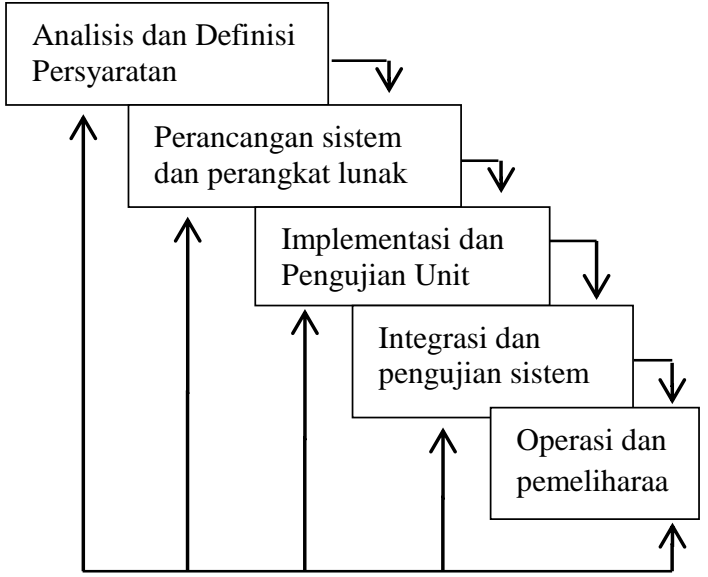

Gambar. 1 Waterfall Model [3].

\section{Implementasi dan Pengujian Unit}

Pada tahap ini, perancangan perangkat lunak direalisasikan sebagai program atau unit program.Kemudian pengujian unit melibatkan verifikasi bahwa setiap unit program telah memenuhi spesifikasinya.

4. Integrasi dan Pengujian Sistem

Unit Program/program individual diintegrasikan menjadi sebuah kesatuan sistem dan kemudian dilakukanpengujian. Dengan kata lain, pengujian ini ditujukanuntuk menguji kebutuhan dari tiap-tiap fungsi perangkat lunak untuk menjamin bahwa persyaratan sistem telah terpenuhi. Setelah pengujian sistem selesai dilakukan, perangkat lunak dikirim ke pelanggan/user.

5. Operasi dan Pemeliharaan

Tahap ini biasanya memerlukan waktu yang paling lama.Sistem diterapkan (di-install) dan dipakai.Pemeliharaan mencakup koreksi dari beberapa kesalahan yang tidak ditemukan pada tahap sebelumnya, perbaikan atas implementasi unit sistem dan pengembangan pelayanan sistem, sementara persyaratan baru ditambahkan [4].

\section{PEKERJAAN DAN DISKUSI HASIL}

\section{A. Analisa}

Proses analisa atau analisis dibagi menjadi dua yaitu analisis kebutuhan fungsional dan analisis kebutuh non fungsional di antaranya sebagai berikut:

1. Analisis Kebutuhan Fungsional

Analisis kebutuhan fungsional dapat digambarkan dengan menggunakan use case diagram. Use case diagram adalah gambaran dari beberapa atau seluruh aktor dan use case dengan tujuan mengenali interkasi mereka dalam suatu sistem. Ada dua hal utama pada use case yaitu pendefinisian apa yang disebut aktor dan use case yaitu:

a. Aktor merupakan orang, proses, atau sistem lain yang berinteraksi dengan sistem informasi yang akan dibuat di luar sistem informmasi itu sendiri, jadi walaupun simbol dari aktor adalah gambar orang, tapi aktor belum tentu merupakan orang.

b. Use case merupakan fungsionalitas yang disediakan sistem sebagai unit-unit yang saling bertukar pesan antar unit atau aktor (Sugiarti, 2013). 
Gambaran Use Case Diagram aplikasi dapat dilihat pada gambar 2 .

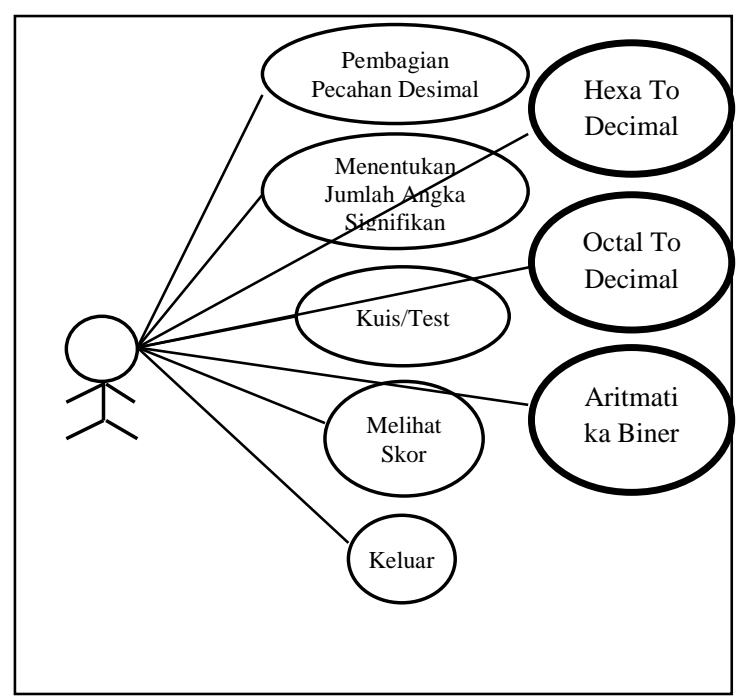

Gambar 2 Use Case Diagram Perangkat Lunak

2. Analisis Kebutuhan Non Fungsional

Analisis non fungsional adalah sebuah tahap dimana akan dilakukan analisis terhadap sumber daya yang digunakan dalam perangkat lunak yang dibangun, sehingga dapat ditentukan kompatibilitas aplikasi yang dibangun terhadap sumber daya yang ada.

1. Analisis Perangkat Keras (Hardware)

Perangkat keras yang digunakan aplikasi ini memiliki spesifikasi Processor Intel Core i3 $3.2 \mathrm{GHz}$, RAM 2 GB, VGA $512 \mathrm{MB}$, Harddisk 320 GB, Monitor SVGA dengan resolusi maksimal 1024 x 728, Mouse dan Keyboard.

2. Analisis Perangkat Lunak (Software)

Analisis yang telah dilakukan dalam kebutuhan software untuk pengembangan dan menjalankan yang disarankan adalah Sistem Operasi Windows 764 bit dan Net Framework 4.0

3. Analisa Pengguna (User)
Yang merupakan pengguna dari perangkat lunak atau aplikasi ini adalah siswa.

\section{B. Perancangan}

Perancangan merupakan bagian dari metode pengembangan sistem yang harus dilakukan setelah proses analisis atau analisa selesai. Pada tahapan ini, akan dilakukan perancangan perangkat lunak aplikasi diantaranya:

a. Rancangan tampilan awal, rancangan tampilan form pembagian pecahan desimal

b. Rancangan tampilan form belajar menentukan jumlah angka signifikan pecahan desimal

c. Rancangan tampilan form heksa to desimal

d. Rancangan tampilan form oktal to desimal

e. Rancangan tampilan form aritmatika biner

f. Rancangan tampilan form kuis/test

g. Rancangan tampilan melihat skor.

\section{Tampilan Awal}

Pada tampilan awal terdapat 4 ikon yang merupakan fitur utama pada aplikasi yang terdiri dari belajar, angka signifikan, kuis/test dan skor. Fitur belajar merupakan fitur untuk belajar mengenai pembagian pecahan desimal dengan pendekatan metode numerik, fitur angka signifikan merupakan fitur untuk belajar menentukan jumlah angka signifikan, fitur kuis/test merupakan fitur untuk mengikuti kuis dan fitur skor merupakan fitur untuk melihat skor dari kuis yang telah diikuti. 


\section{http://jurnal.unprimdn.ac.id/index.php?journal=JUSIKOM}

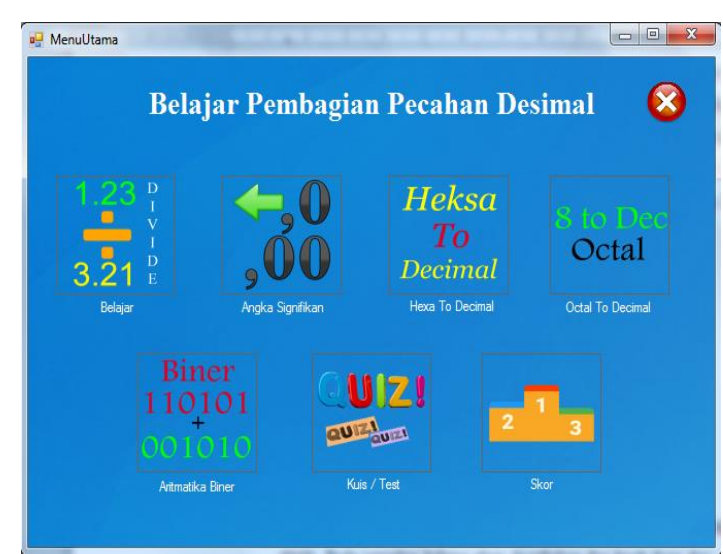

Gambar 3 TampilanAwal

\section{a. Tampilan Belajar}

Tampilan Belajar akan muncul apabila ikon Belajar pada tampilan awal diklik. Pada tampilan belajar akan disediakan dua buah form dan user tinggal mengisi bilangan pertama dan kedua desimal yang ingin dibagikan, lalu menekan tombol bagikan, maka secara otomatis akan muncul kotak penjelasan di bawahnya.

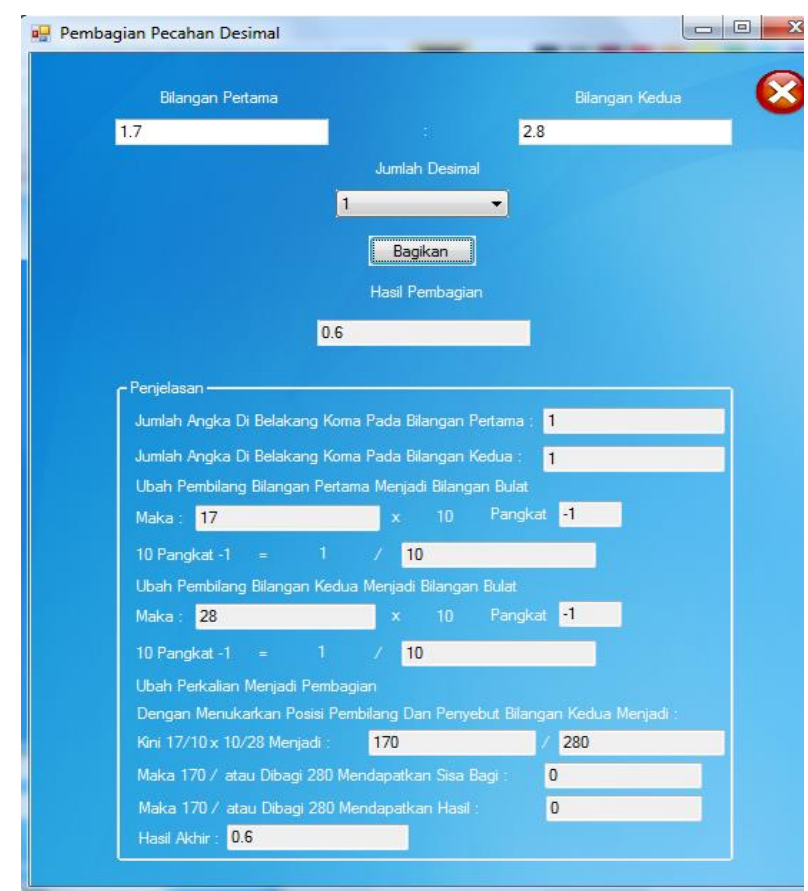

Gambar 4 Tampilan Belajar

\section{b. Tampilan Heksa To Desimal}

Tampilan Heksa To Decimal akan muncul apabila ikon Heksa To Desimal pada tampilan awal diklik. Pada tampilan ini akan disediakan sebuah form dan user tinggal mengisinya dengan bilangan heksa dan kemudian menekan tombol konversikan, maka secara otomatis akan muncul kotak penjelasan dan hasilnya.

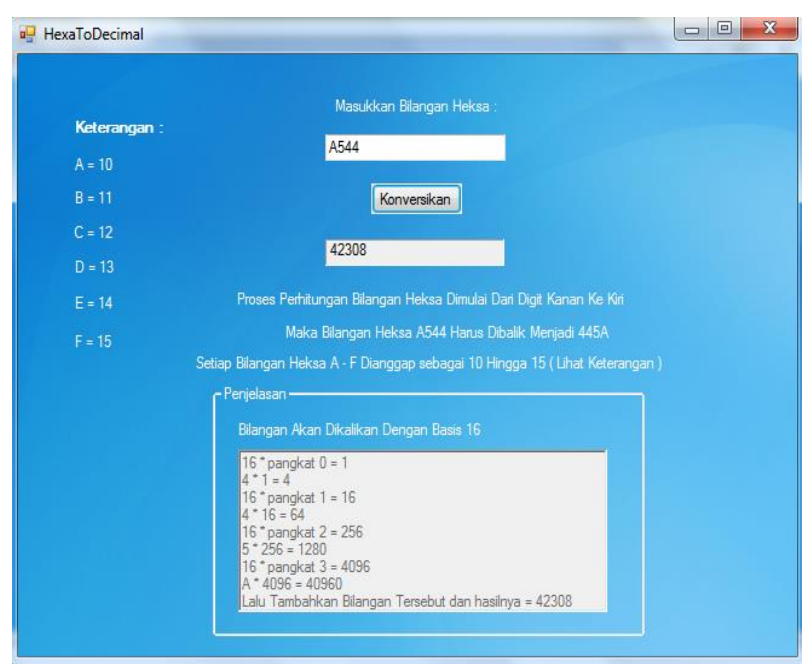

Gambar 5 Tampilan Heksa To Desimal

\section{c. Tampilan Oktal To Desimal}

Tampilan Oktal To Decimal akan muncul apabila ikon Oktal To Desimal pada tampilan awal diklik. Pada tampilan ini akan disediakan sebuah form dan user tinggal mengisinya dengan bilangan oktal dan kemudian menekan tombol konversikan, maka secara otomatis akan muncul kotak penjelasan dan hasilnya.

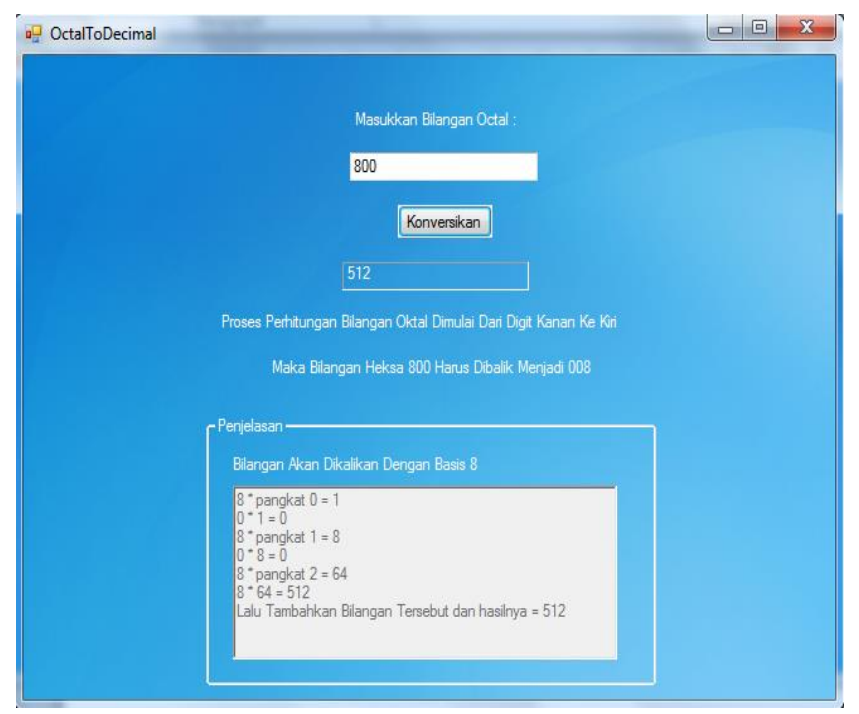

Gambar 6 Tampilan Oktal To Desimal

\section{d. Tampilan Aritmatika Biner}




\section{http://jurnal.unprimdn.ac.id/index.php?journal=JUSIKOM}

Tampilan Aritmatika Biner akan muncul apabila ikon Aritmatika Biner pada tampilan awal diklik. Pada tampilan ini akan disediakan dua buah form dan user tinggal mengisinya dengan bilangan biner dan kemudian menekan tombol jumlahkan, maka secara otomatis akan muncul kotak penjelasan dan hasilnya.

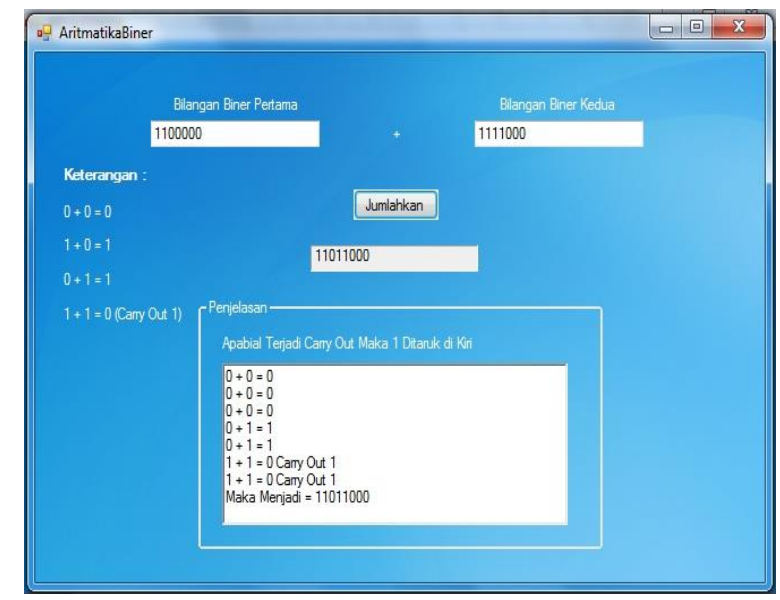

Gambar 7 Tampilan Aritmatika Biner

\section{e. Tampilan Angka Signifikan}

Tampilan Angka Signifikan akan muncul apabila ikon Angka Signifikan pada tampilan awal diklik. Pada tampilan angka signifikan akan disediakan sebuah form dan user, sehingga hanya perlu mengisi bilangan desimal yang ingin ditentukan angka signifikannya, lalu menekan tombol proses, maka secara otomatis akan muncul kotak penjelasan.

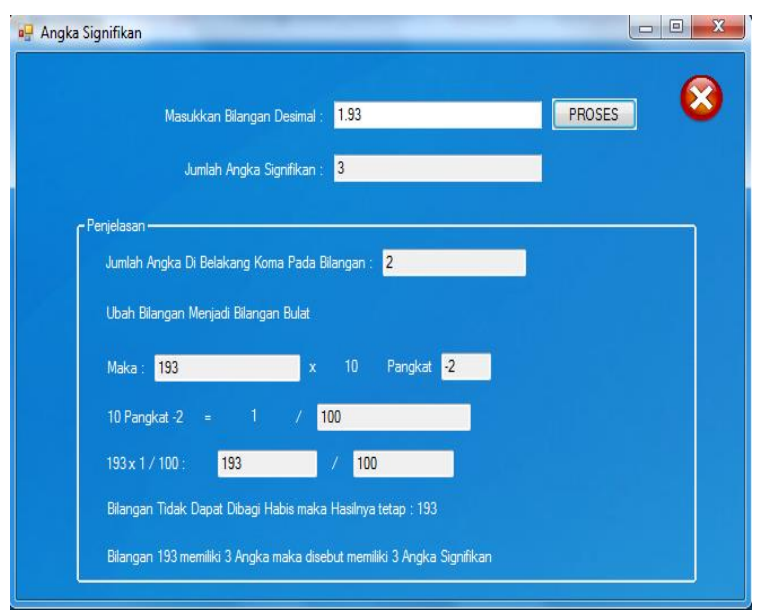

Gambar 8 Tampilan Angka Signifikan

\section{f. Tampilan Kuis/Test}

Tampilan Kuis/Test akan muncul apabila ikon kuis/test pada tampilan awal diklik. Pada tampilan kuis/test akan disediakan dua buah form yang harus diisi berupa nama dari user dan nomor induk pelajar dari user.

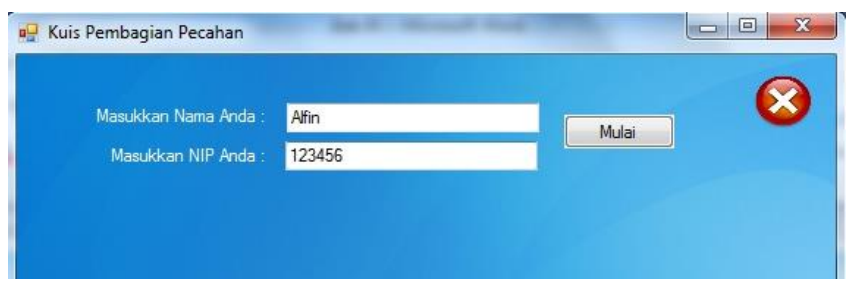

Gambar 9 Tampilan Isi Form Nama

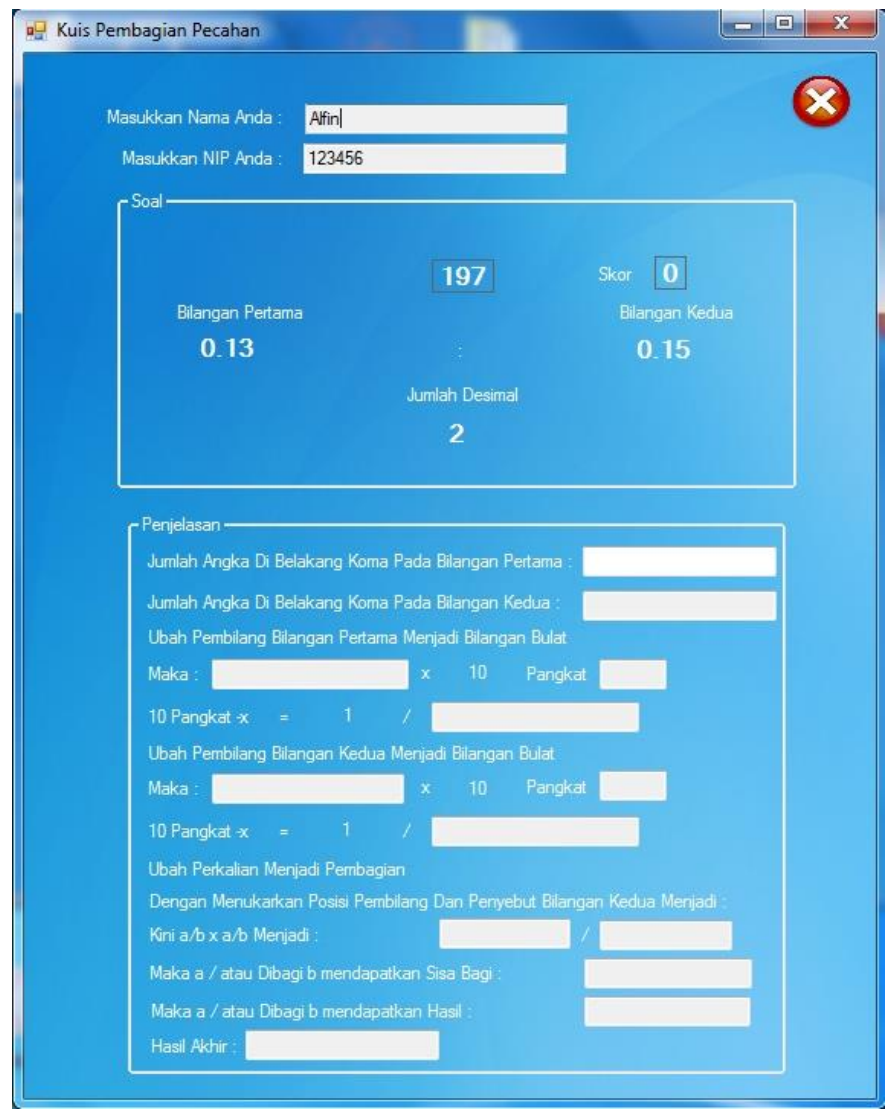

Gambar 10 Tampilan Mulai Kuis

Lalu isilah form yang dapat diisi, apabila jawaban benar maka form isian selanjutnya akan terbuka dan seterusnya hingga mencapai form isian terakhir. 


\section{http://jurnal.unprimdn.ac.id/index.php?journal=JUSIKOM}

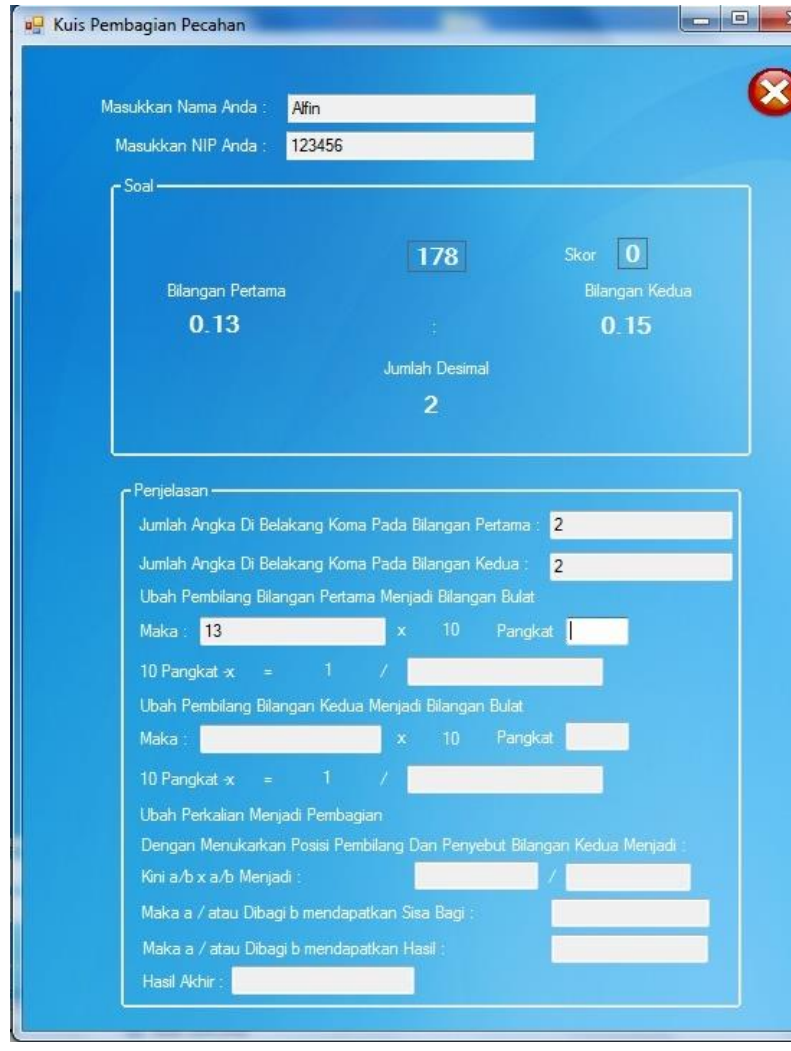

Gambar 11 Tampilan Mengisi Form Isian

Secara otomatis sistem akan menampilkan pertanyaan selanjutnya dan skor akan bertambah sebanyak 10 apabila jawaban yang dijawab benar.

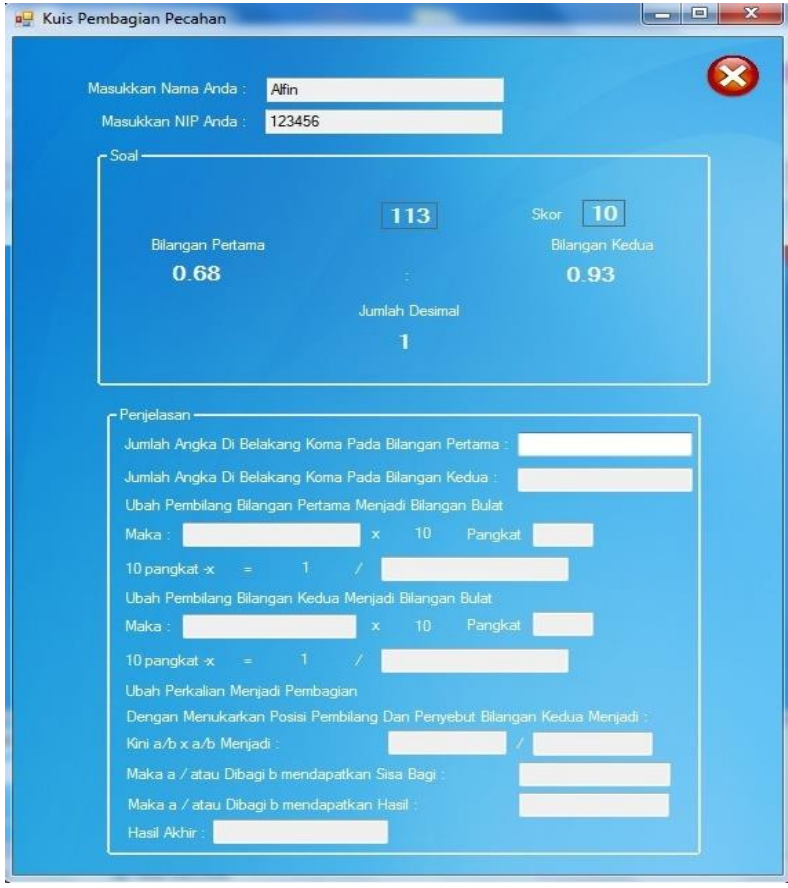

Gambar 12 Tampilan Skor Bertambah
Apabila waktu telah habis maka secara otomatis akan muncul kotak yang menanyakan apakah data peserta ingin disimpan atau tidak di list skor. Jika mengklik OK maka secara otomatis skor akan disimpan ke database dan apabila mengklik cancel, maka form ditutup dan kembali ke tampilan utama.

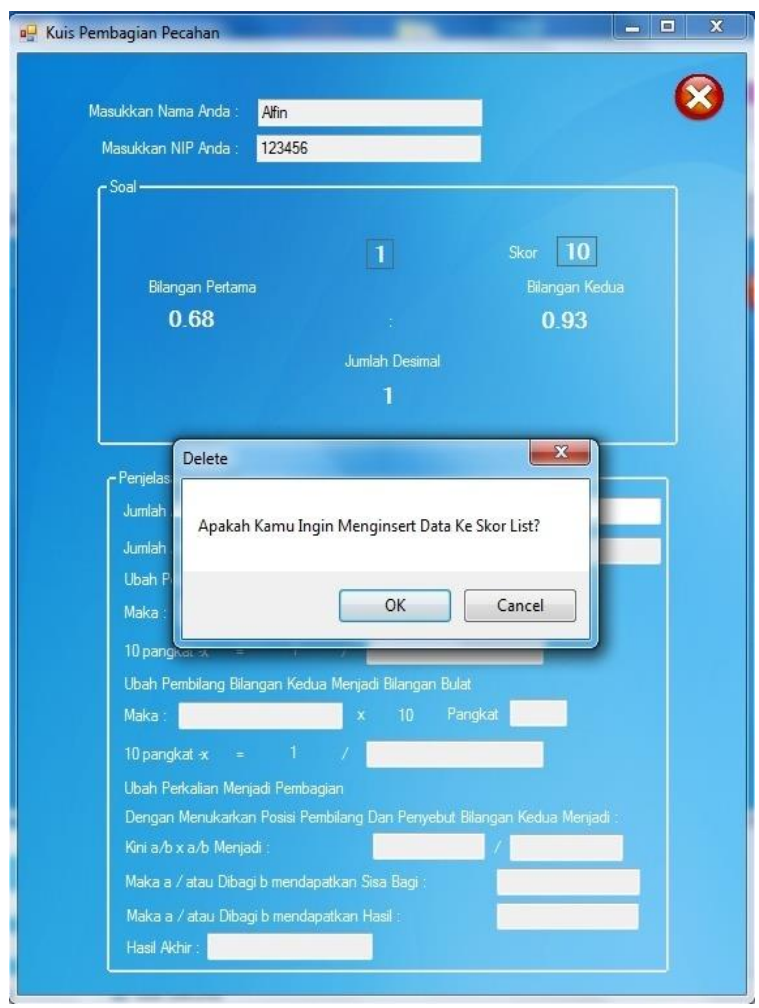

Gambar 1 Tampilan Simpan Data

\section{g. Tampilan Skor}

Tampilan Skor akan muncul apabila ikon skor pada tampilan awal diklik. Pada tampilan skor akan ditampilkan data peserta yang pernah mengikuti test dengan skor tertinggi di posisi paling atas. Tabel skor akan memberikan informasi mengenai nama peserta, nip peserta serta skor yang berhasil diraih.

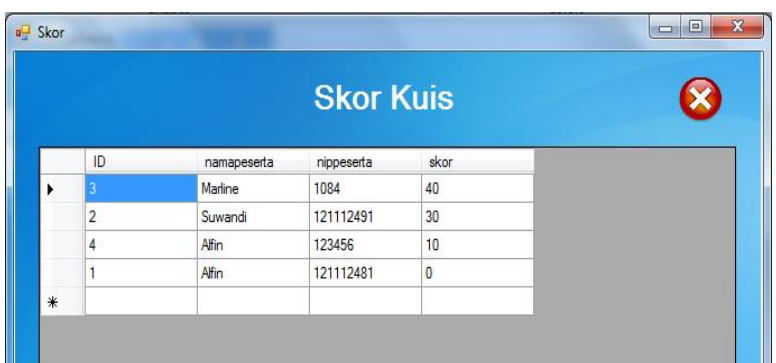

Gambar 14 Tampilan Skor 


\section{http://jurnal.unprimdn.ac.id/index.php?journal=JUSIKOM}

\section{h. Tampilan Keluar}

Untuk keluar dari aplikasi user cukup menekan tombol $\mathrm{X}$ yang ada di sebelah kanan aplikasi.

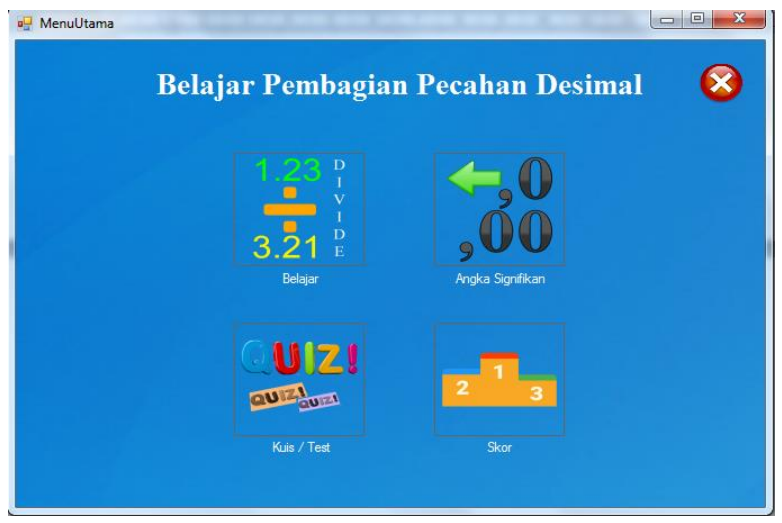

Gambar 2 Tampilan Keluar

\section{KESIMPULAN}

Berdasarkan hasil dan pembahasan diperoleh beberapa kesimpulan, yaitu:

a. Perangkat lunak memberikan penjelasan yang mudah mengenai cara pembagian pecahan desimal secara bertahap. Pada tahapan tersebut akan dijelaskan hasil dari pembagian pecahan tersebut sehingga user lebih mengerti mengenai pecahan desimal

b. Perangkat lunak dapat dijalankan pada komputer desktop dan tidak memerlukan internet untuk menjalankannya, karena perangkat lunak bersifat offline dan dapat dijalankan selama memiliki komputer dengan spesifikasi yang standar

\section{DAFTAR PUSTAKA}

[1] Djojodiharjo, H. 2000. Metode Numerik. Jakarta : PT. Gramedia Pustaka Utama.

[2] Chapra, S.C. \& Canale, R.P. 2010. Numerical Methods for Engineers Sixth Edition. New York: McGraw Hill.

[3] Sommerville, I., Software Engineering (Rekayasa Perangka tLunak). Yogyakarta: Andi.

[4] Pressman, R.S. 2010. Software Engineering : a practitioner's approach, New York: McGraw-Hill. 